\title{
PEMAAFAN DAN KEBAHAGIAAN PADA LANSIA
}

\author{
Putri Pusvitasari, Arini Mifti Jayanti \\ Program Studi Psikologi Fakultas Ekonomi dan Sosial \\ Universitas Jenderal Achmad Yani Yogyakarta \\ E-mail:putripusvitasari@gmail.com,arinimiftijay@gmail.com
}

\begin{abstract}
The purpose of this research is to identify the relationship between forgiveness and happiness in elderly at Wredha Abiyoso Pakem Yogyakarta house. The subject are 30 seniors who live at the house. This research uses two scales, those are forgiveness scale which has 10 items and refers to Nashori (2011) and happiness scale which has 20 items and refers to seligman's happiness scale (2005). The data analysis which is used in the research is product moment from pearson. The result shows that there is a significant relationship between forgiveness and happiness in the elderly who live in the Werdha Abiyoso Pakem Yogyakarta house. It is proven by correlation coefficient between forgiveness and happiness for $r=$ 0,533 with $p=0,000(p<0,01)$.
\end{abstract}

Key words : Forgiveness, Happiness

\begin{abstract}
Abstrak
Penelitian ini bertujuan untuk mengetahui hubungan antara pemaafan dan kebahagiaan para lansia yang tinggal di panti wredha Abiyoso Pakem, Yogyakarta. Subjek yang terlibat dalam penelitian ini adalah 30 orang para lansia yang tinggal di panti tersebut. Penelitian ini menggunakan dua buah skala, yaitu : skala pemaafan (10 aitem) yang mengacu pada aspek pemaafan dari Nashori (2011) dan skala kebahagiaan (20 aitem) yang mengacu pada aspek kebahagiaan milik Seligman (2005). Analisis data yang digunakan dalam penelitian ini adalah tehnik korelasi Product Moment dari Pearson. Hasil menunjukkan bahwa ada hubungan yang signifikan antara pemaafan dengan kebahagiaan para lansia yang tinggal di panti wredha Abiyoso Pakem, Yogyakarta. Hal ini dibuktikan dengan besarnya koefisien korelasi antara pemaafan dengan kebahagiaan para lansia sebesar $r=0,533$ dengan $\mathrm{p}=$ $0,000(\mathrm{p}<0,01)$.
\end{abstract}

Kata kunci: Pemaafan, Kebahagiaan

\section{PENDAHULUAN}

Lanjut usia (lansia) adalah suatu proses yang pasti dialami oleh individu yang diberi karunia umur panjang. Proses tersebut akan terjadi terus menerus dan berkelanjutan. Menurut data Biro Pusat Statistik (BPS) (Wiyono \& Widodo, 2010) Indonesia memiliki jumlah penduduk 147,3 juta. Dari angka tersebut terdapat 6,3 juta orang $(4,3 \%)$ berusia 60 tahun ke atas. Dari 6,3 juta orang tersebut terdapat $822.831(13,06 \%)$ orang 
tergolong jompo, yaitu para lansia yang memerlukan bantuan khusus sesuai undangundang bahkan mereka harus dipelihara oleh negara. Banyaknya masyarakat lansia menyebabkan munculnya perhatian yang lebih dari berbagai pihak untuk mensejahterakan kehidupan lansia. Kebutuhan lansia yang berbeda dengan masyarakat lainnya membuat usaha yang dilakukan untuk mensejahterakan masyarakat lansia pun berbeda dengan masyarakat lainnya. Salah satu perhatian yang dilakukan pemerintah Indonesia terhadap para lansia adalah dengan menampung para lansia di panti wreda.

Adapun lansia yang tinggal di panti sosial Tresna Wreda Abiyoso Pakem Yogyakarta tentunya memiliki alasan yang berbeda dan beragam. Sebagian besar alasan atau latar belakang yang membuat mereka harus tinggal di panti disebabkan karena kurangnya perhatian atau dukungan dari keluarga, seperti beberapa subjek yaitu subjek TI yang harus tinggal di panti karena akan dibunuh anaknya yang memaksa untuk diberikan warisan. Adapun subjek RY yang harus tinggal dipanti karena tidak pernah menikah dan saudara maupun keluarga lainya tidak mau merawatnya. Begitupun Subjek JL yang harus tinggal dipanti karena anak-anaknya mengaku tidak sanggup merawatnya yang pada akhirnya meminta JL untuk pergi dari rumah, hal ini membuat JL terlantar yang pada akhirnya panti mengambilnya. Kondisi yang dialami oleh para lansia yang tinggal di panti tersebut membuat mereka mudah marah, cemas, kecewa, dan lain-lain (Jayanti, 2014).

Salah satu contohnya adalah seorang nenek yang tinggal di panti sosial Tresna Werda Abiyoso Pakem Sleman Yogyakarta, dimana nenek tersebut marah hanya karena jemurannya terpercik air putih oleh temannya. Hal tersebut menunjukkan adanya peluang terjadinya suatu konflik dengan sesama lansia yang tinggal di panti wreda. Konflik yang terjadi dapat mengganggu aktivitas para lansia sehari-hari sehingga membuat mereka mudah marah dan kecewa terhadap temannya. Hal ini pada akhirnya membuat para lansia merasa tidak nyaman.

Kasus lainnya ditemukan berdasarkan wawancara yang dilakukan pada lansia yang tinggal di panti sosial Tresna Wreda Abiyoso Pakem. Ada seorang nenek yang menceritakan pengalamannya mengenai konflik yang sering terjadi antara para penghuni panti. Konflik yang terjadi antara lain adalah nenek M yang menceritakan bahwa beliau merasa sakit hati dengan teman sekamarnya yaitu nenek S. Hal ini terjadi karena adanya kesalahpahaman, dimana ketika nenek $M$ sedang berbicara, nenek $S$ mempersepsikan bahwa nenek $M$ sedang memarahinya. Padahal nenek $M$ berbicara dengan nada yang sedikit tinggi karena pendengaran nenek S kurang baik akibat faktor usia. Kesalahpahaman itu membuat nenek M merasa kurang nyaman dan belum bisa memaafkan nenek $\mathrm{S}$, sehingga hal ini membuat nenek $\mathrm{M}$ menjadi tidak bahagia tinggal di panti.

Kebahagiaan dalam hidup merupakan dambaan setiap manusia tidak terkecuali individu lanjut usia. Masa tua seharusnya dijalani dengan bahagia dan sejahtera, keadaan seperti ini hanya dapat dicapai apabila individu tersebut merasa sehat secara 
fisik, mental, dan sosial, merasa dibutuhkan, merasa dicintai, mempunyai harga diri serta dapat berpartisipasi dalam kehidupan (Idris, dkk dalam Santoso \& Lestari, 2008). Menurut Aiken (Wismanto, 2011), kebahagiaan berkaitan langsung dengan apa yang dirasakan oleh lansia serta persepsi lansia tersebut mengenai kondisi dirinya. Lansia dengan kepuasan hidup yang tinggi dengan tidak bersikap sinis terhadap orang lain, tidak egois, memiliki sikap positif terhadap diri sendiri dan orang lain akan mengacu kepada perasaan bahagia.

Menurut Stanley dan Beare (2012) kondisi kesehatan pada lansia akan mempengaruhi aktivitas lansia hal ini menyebabkan munculnya masalah sosial seperti ketidakmampuan fisik dan gangguan psikologis pada lansia. Sejalan dengan pernyataan Stanley dan Beare (2012) bahwa kebahagiaan dan kesehatan pada lansia merupakan dua hal yang tidak dapat dipisahkan karena keduanya saling mempengaruhi satu sama lain. Namun realitanya berdasarkan observasi dan wawancara yang dilakukan di panti sosial Tresna Werda Abiyoso Pakem Sleman Yogyakarta menunjukkan bahwa lansia yang berada di panti tersebut sering mengalami konflik dengan temannya sehingga membuat hubungan sosialnya kurang sehat yang nantinya akan membuat lansia yang tinggal di panti tersebut merasa tidak bahagia.

Faktor kebahagiaan menurut Seligman (2005) terdapat faktor eksternal dan faktor internal. Terdapat tiga faktor internal menurut Seligman (2005) yaitu: kepuasan terhadap masa lalu yang dicapai melalui tiga cara seperti melepaskan pandangan masa lalu terhadap masa depan, bersyukur, memaafkan dan melupakan. Konflik yang terjadi pada lansia dengan temannya akan membuat lansia merasa tidak bahagia, namun dengan memaafkan akan membuat lansia menerima kesalahan lansia lain yang akan memperbaiki hubungan sosialnya menjadi lebih baik sehingga lansia tersebut menjalani kehidupan dengan bahagia.

Zainuddin (2011) melakukan penelitian dengan judul dendam dan pemaafan dalam konflik antara kelompok. Hasil penelitian tersebut menunjukkan bahwa penyebab perilaku buruk pada anggota kelompok dianggap sebagai ancaman bagi kelompok yang lain, pemaknaan budaya Siri na pace yang salah yang salah antar kelompok maupun individu akan memunculkan dendam dan gagalnya usaha-usaha untuk memaafkan. Siri mengandung makna kewajiban untuk menjaga harga diri dan kehormatan, sedangkan Pacce mengandung makna rasa kesetiakawanan dan kepedulian sosial. Dengan memaafkan akan membuat seseorang dapat merefleksikan dirinya sehingga bisa mendapatkan kebahagiaan dalam kehidupan yang dijalaninya.

Selain itu, hasil penelitian lain dari Toussaint dan Friedman (2009) menunjukkan bahwa pemaafan dan kebersyukuran memiliki hubungan positif dengan kebahagiaan. Kebahagiaan tersebut dimediasi oleh pengaruh dan kepercayaan. Hasil penelitian tersebut diperkuat oleh penelitian yang dilakukan oleh Maltby, Day dan Barber (2005) yang menunjukkan bahwa pemaafan memberikan sumbangan yang signifikan terhadap 
kebahagiaan. Kebahagiaan tersebut terlibat dalam perilaku dan perasaan yang positif dalam jangka waktu yang lama.

Menurut Nashori (2011), pemaafan merupakan kesediaan untuk meninggalkan halhal yang tidak menyenangkan yang bersumber dari hubungan interpersonal dengan orang lain dan menumbuhkembangkan pikiran, perasaan, dan hubungan interpersonal yang positif dengan orang lain yang melakukan pelanggaran secara tidak adil. Fincham, Hall, dan Beach (2006) menyatakan bahwa memberi maaf adalah solusi terbaik untuk mengatasi ketidaksetiaan dalam suatu hubungan. Lansia panti wreda yang memiliki konflik dengan temannya akan merasa tidak nyaman dan memiliki hubungan yang kurang baik dengan sosialnya. Hal ini pada akhirnya membuat lansia yang tinggal di panti wreda merasa kurang bahagia dalam menjalani kehidupannya.

Berdasarkan latar belakang yang dikemukakan di atas, maka dari penelitian ini dapat ditarik hipotesis bahwa ada hubungan antara pemaafan dan kebahagiaan pada lansia yang tinggal di panti sosial Tresna Wreda Abiyoso Pakem Yogyakarta.

\section{Pemaafan}

Secara terminologis, kata dasar dari pemaafan adalah maaf dan kata maaf adalah kata saduran dari bahasa Arab, al'afw. Kata tersebut memiliki makna yang berarti keterhapusan. Pada dasarnya, menurut Philpot (Ghani, 2011), pemaafan merupakan sebuah proses (atau hasil dari proses) yang meliputi perubahan perasaan dan sikap terhadap pelaku. Pemaafan menurut McCullogh (McCullogh, Fincham, \& Tsang, 2003) merupakan suatu sikap seseorang yang telah disakiti untuk tidak melakukan perbuatan balas dendam terhadap pelaku, tidak adanya keinginan untuk menjauhi pelaku, sebaliknya adanya keinginan untuk berdamai dan berbuat baik terhadap pelaku, walaupun pelaku telah melakukan perilaku yang menyakitkan.

Hal serupa juga dikemukakan oleh Nashori (2011), pemaafan merupakan perasaan kesediaan untuk meninggalkan hal-hal yang tidak menyenangkan yang bersumber dari hubungan interpersonal dengan orang lain dan menumbuhkembangkan pikiran, perasaan, dan hubungan interpersonal yang positif dengan orang lain yang melakukan pelanggaran secara tidak adil. Sedangkan Menurut Ghani (2011), pemaafan adalah state of mind yang melibatkan pikiran, perasaan, dan tindakan hal tertentu, yaitu memaafkan merupakan proses melepaskan rasa nyeri, kemarahan, dan dendam terhadap pelaku yang telah menyakiti perasaan.

Kemudian Hadriami (2008) memberi pengertian bahwa pemaafan adalah kesediaan dari pihak yang dicederai untuk memberikan maaf atau memaafkan pihak yang telah mencederai. Pemaafan merupakan kesediaan menanggalkan kekeliruan masa lalu yang menyakitkan, tidak lagi mencari-cari nilai dalam amarah dan kebencian, serta menepis keinginan untuk menyakiti orang lain atau diri sendiri. 


\section{Kebahagiaan}

Dalam Kamus Besar Bahasa Indonesia (1990) disebutkan bahwa kebahagiaan adalah perasaan bahagia, terdapat kesenangan dan ketenteraman hidup baik lahir dan batin. Kebahagiaan adalah keadaan pikiran atau perasaan yang ditandai dengan adanya kepuasan, cinta, kesenangan, atau sukacita (Cambridge Advanced Learner's Dictionary dalam Aziz, 2011). Di dalam bukunya, Hurlock (2000) mendefinisikan kebahagiaan sebagai suatu keadaaan sejahtera dan kepuasan hati, yaitu kepuasan yang menyenangkan yang timbul bila kebutuhan dan harapan tertentu individu terpenuhi. Veenhoven (Anggoro \& Widhiarso, 2010) mendefinisikan kebahagiaan sebagai derajat sebutan terhadap kualitas hidup yang menyenangkan dari seseorang.

Lazarus (Franken, 2002) mendefinisikan kebahagian dengan sangat menarik, yaitu sebagai cara membuat langkah-langkah progres yang masuk akal untuk merealisasikan suatu tujuan. Dengan definisi tersebut di atas maka manusia dituntut untuk lebih proaktif dalam mencari dan memperoleh kebahagiaan. Definisi yang dikemukakan oleh Lazarus tersebut menempatkan kebahagiaan yang selama ini dipandang sebagai aspek afektif belaka untuk masuk dan berada dalam ruang logika dan kognitif manusia sehingga dapat direalisasikan dengan langkah yang jelas.

Secara lebih lanjut, Lazarus (Franken, 2002) juga mengatakan bahwa kebahagiaan mewakili suatu bentuk interaksi antara manusia dengan lingkungan. Dalam hal ini, manusia bisa saja bahagia sendiri dan bahagia untuk dirinya sendiri, tetapi di sisi lain ia juga bisa bahagia karena orang lain dan untuk orang lain. Hal ini sekaligus memberikan kenyataan lain bahwa kebahagiaan tidak bersifat egositis melainkan dapat dibagi kepada orang lain dan lingkungan sekitar. Sedangkan Seligman (2005) mengemukakan bahwa kebahagiaan merupakan suatu istilah yang menggambarkan perasaan positif serta kegiatan positif tanpa unsur perasaan positif (seperti ekstase atau kenyamanan) serta kegiatan positif tanpa unsur perasaan sama sekali (seperti keterserapan dan keterlibatan).

\section{METODE}

\section{Partisipan}

Partisipan dalam penelitian ini adalah lansia yang tinggal di panti sosial Tresna Wredha Abiyoso Pakem Yogyakarta, baik itu yang berjenis kelamin pria maupun wanita dan berusia di atas 60 tahun. Kemudian dari populasi dengan karakteristik tersebut di atas diambil sebanyak 30 orang sebagai sampel. 


\section{Desain Penelitian}

Teknik pengambilan sampel yang digunakan dalam penelitian ini adalah purposive sampling. Pengambilan data pada penelitian ini menggunakan metode skala.

\section{Instrumen Penelitian}

Variabel pemaafan diukur dengan menggunakan skala pemaafan berdasarkan dimensi pemaafan yang disusun berdasarkan kesimpulan dari teori yang dikemukakan oleh Nashori (2011). Adapun dimensi pemaafan yang disebutkan ada tiga, yaitu dimensi emosi pemaafan, dimensi kognisi pemaafan, dan dimensi interpersonal pemaafan. Jumlah aitem dalam skala ini adalah 20 butir aitem dengan nilai reliabilitas sebesar 0,95 .

Sedangkan variabel kebahagiaan diukur dengan menggunakan skala kebahagiaan berdasarkan aspek-aspek kebahagiaan yang disusun berdasarkan kesimpulan dari teori yang dikemukakan oleh Seligman (2005). Adapun aspek-aspek kebahagiaan yang disebutkan ada lima, yaitu terjalinnya hubungan positif dengan orang lain, keterlibatan penuh, penemuan makna dalam hidup, optimisme yang realistis, dan resiliensi. Jumlah aitem dalam skala ini adalah 10 butir aitem dengan nilai reliabilitas sebesar 0,92.

\section{Analisis Data}

Teknik analisis data yang digunakan dalam penelitian ini adalah teknik product moment Pearson dibantu dengan program SPSS versi 16.0. Uji korelasi ini bertujuan untuk mencari hubungan antara dua variabel penelitian, yaitu pemaafan terhadap kebahagiaan.

\section{HASIL}

Variabel pemaafan diketahui memiliki skor terendah 41 dan skor tertinggi 60, dengan nilai rata-rata 49,17 dan standar deviasi $(S D)$ sebesar 6,721. Sedangkan variabel kebahagiaan memiliki nilai rata-rata 24,83 dan standar deviasi $(S D)$ sebesar 3,582, dengan skor tertinggi 31 dan skor terendah 20.

Tabel 1

Deskripsi Statistik

\begin{tabular}{cccccc}
\hline & N & Min & Maks & Rata-Rata & SD \\
\hline Pemaafan & 30 & 41 & 60 & 49,17 & 6,721 \\
Kebahagiaan & 30 & 20 & 31 & 24,83 & 3,582 \\
\hline
\end{tabular}


Berdasarkan hasil analisis yang telah dilakukan, diketahui bahwa koefisien korelasi antara pemaafan dan kebahagiaan adalah sebesar 0,533 dengan taraf signifikansi 0,000 $(\mathrm{p}<0,01)$. Hal ini menunjukkan bahwa pemaafan dan kebahagiaan memiliki korelasi yang cukup kuat. Nilai positif pada koefisien korelasi menandakan antara kedua variabel memiliki hubungan dengan arah yang positif. Dapat diartikan bahwa ada kecenderungan semakin kuat pemaafan, maka semakin tinggi kebahagiaan yang dimiliki oleh lansia. Begitu pula sebaliknya, semakin rendah pemaafan, maka semakin sedikit juga kebahagiaan yang dirasakan lansia.

Selain itu, hasil analisis juga menunjukkan besaran $\mathrm{R}$ square $\left(\mathrm{R}^{2}\right)$ pemaafan pada kebahagiaan adalah sebesar 0,533 yang artinya besarnya pengaruh variabel pemaafan terhadap kebahagiaan adalah 53,3\%, sedangkan sisanya 46,7\% dipengaruhi oleh variabel atau aspek lain yang ada di luar penelitian ini.

\section{PEMBAHASAN}

Tujuan dilakukannya penelitian ini adalah untuk menguji apakah terdapat hubungan antara pemaafan dan kebahagiaan pada lansia. Berdasarkan hasil uji hipotesis yang telah dilakukan, diketahui bahwa koefisien korelasi antara pemaafan dan kebahagiaan adalah sebesar 0,533 dengan taraf signifikansi 0,000 ( $\mathrm{p}<0,01)$. Hal ini menunjukkan bahwa ada hubungan yang signifikan antara pemaafan dan kebahagiaan pada lansia di panti sosial Tresna Wredha Abiyoso Pakem Yogyakarta.

Menurut Aiken (Wismanto 2011), kebahagiaan berkaitan langsung dengan apa yang dirasakan oleh lansia serta persepsi lansia tersebut mengenai kondisi dirinya. Lansia dengan kepuasan hidup yang tinggi dengan tidak bersikap sinis terhadap orang lain, tidak egois, memiliki sikap positif terhadap diri sendiri dan orang lain akan mengacu kepada perasaan bahagia. Pada individu usia lanjut, kebahagiaan dan kesehatan merupakan dua hal yang tidak dapat dipisahkan karena keduanya saling mempengaruhi satu sama lain.

Salah satu faktor yang mempengaruhi kebahagiaan adalah pemaafan. Di dalam Alquran QS. Asy Syuura ayat 40-43 disebutkan bahwa:

"Dan balasan suatu kejahatan adalah kejahatan yang serupa, maka barang siapa memaafkan dan berbuat baik maka pahalanya atas (tanggungan) Allah. Sesungguhnya Dia tidak menyukai orang-orang yang zalim. Dan sesungguhnya orang-orang yang membela diri sesudah teraniaya, tidak ada satu dosapun terhadap mereka. Sesungguhnya dosa itu atas orang-orang yang berbuat zalim kepada manusia dan melampaui batas di muka bumi tanpa hak. Mereka itu mendapat azab yang pedih. Tetapi orang yang bersabar dan mema'afkan, sesungguhnya (perbuatan) yang demikian itu termasuk hal-hal yang diutamakan." 
Ayat tersebut menerangkan bahwa orang-orang yang sabar dan memaafkan perbuatan jahat yang dilakukan oleh orang lain atas dirinya, maka ia akan dimuliakan oleh Allah dan ditolongnya serta akan diberikan oleh Allah tambahan rezeki yang banyak sehingga hal ini dapat membuat orang tersebut menjadi bahagia (Shihab, 2002) . Hal tersebut tidak jauh berbeda dengan yang dikemukakan oleh Seligman (2005) bahwa tiga faktor internal dari kebahagiaan adalah kepuasan terhadap masa lalu yang dicapai melalui tiga cara seperti melepaskan pandangan masa lalu terhadap masa depan, bersyukur, memaafkan dan melupakan. Konflik yang terjadi pada lansia dengan temannya akan membuat lansia merasa tidak bahagia, namun dengan memaafkan akan membuat lansia menerima kesalahan lansia lain yang akan memperbaiki hubungan sosialnya menjadi lebih baik sehingga lansia tersebut menjalani kehidupan dengan bahagia. Jika seorang lansia merasa bahagia dalam hidupnya, maka ia akan dapat memaafkan kesalahan orang yang pernah menyakiti hatinya. Mullet, Houdbine, Laumonier dan Girard (2000) menyatakan bahwa orang tua lebih bersedia untuk memaafkan daripada orang dewasa muda. Hal ini sesuai dengan hasil penelitian yang telah diperoleh yaitu semakin tinggi pemaafan, maka semakin tinggi kebahagiaan pada lansia.

Selain itu, hasil penelitian lain dari Toussaint dan Friedman (2009) menunjukkan bahwa pemaafan dan kebersyukuran memiliki hubungan positif dengan kebahagiaan. Kebahagiaan tersebut dimediasi oleh pengaruh dan kepercayaan. Hasil penelitian tersebut diperkuat oleh penelitian yang dilakukan oleh Maltby, Day dan Barber (2005) yang menunjukkan bahwa pemaafan memberikan sumbangan yang signifikan terhadap kebahagiaan. Kebahagiaan tersebut terlibat dalam perilaku dan perasaan yang positif dalam jangka waktu yang lama.

Kemudian pemberian maaf berdampak pada kebahagiaan psikologis baik itu terhadap pemberi maaf maupun individu yang dimaafkan. Dampak pada pemberi maaf yaitu dapat memperoleh ketenangan yang dapat menghasilkan kebahagiaan sedangkan bagi individu yang dimaafkan akan mendapatkan ketenangan karena telah dimaafkan (Karremans, dkk. dalam Wardhati \& Faturochman, 2006). Hasil penelitian lain yang dilakukan oleh Fincham, Beach, dan Davila (2004) menunjukkan bahwa memaafkan dalam hubungan interpersonal juga erat pengaruhnya terhadap kebahagiaan dan kepuasan hubungan.

Menurut Enright (2001), pemaafan dapat mempengaruhi kesehatan fisik dan psikologis karena dengan pemaafan seseorang dapat melepaskan perasaan marah, mengubah pemikiran destruktif menjadi pemikiran yang lebih baik terhadap orang yang telah menyakitinya. Kemudian Anderson (Paramitasari \& Alfian, 2012) berpendapat bahwa memaafkan merupakan salah satu proses yang dapat mengembalikan hubungan yang rusak dan meningkatkan kesejahteraan secara keseluruhan dengan mengurangi rasa marah. 
Pemaafan juga dapat mengurangi emosi-emosi negatif, rasa benci dan perasaan dendam. Pemaafan tersebut dapat menggantikan emosi negatif dengan emosi positif (Witvliet, Ludwig \& VanderLann, 2001). Berkaitan dengan emosi positif, Worthington, Witvliet, Pietrini dan Miller (2007) dalam hasil penelitiannya menemukan bahwa pemaafan memiliki hubungan dengan kebahagiaan. Penelitian lainnya juga menunjukkan adanya hubungan antara pemaafan dengan kebahagiaan (Sastre, Vinsonneau, Neto, Girard dan Mullet, 2003). Karena pada dasarnya kebahagian memiliki dampak yang positif terhadap seseorang maka seseorang yang bahagia akan memiliki emosi positif yang lebih baik dan lebih bersemangat jika dibandingkan dengan orang yang tidak bahagia (Csikszentmihalyi \& Hunter, 2003)

Sejumlah psikolog di negara maju telah melakukan penelitian dalam sepuluh tahun terakhir ini tentang pemaafan. Berdasarkan penelitian tersebut ditemukan hasil bahwa orang-orang yang mempu memaafkan ternyata memiliki kesehatan jasmani dan rohani yang baik, dimana gejala-gejala seperti susah tidur, sakit punggung, dan sakit perut karena stres menjadi berkurang ketika melakukan pemaafan (Jamal \& Thoif, 2009). Kemudian, mereka yang mampu memaafkan juga mampu mengontrol emosi negatif, mematangkan mental, menjernihkan dan meluaskan hati dan pikiran.

Selain itu, hasil penelitian lain yang dilakukan oleh Luskin menunjukkan hasil bahwa memaafkan dapat menjadi salah hal yang dapat dilakukan ketika seseorang ingin mendapatkan hidup yang sehat dan bahagia. Pemaafan juga dapat memicu terciptanya keadaan yang positif, seperti harapan, kesabaran, dan kepercayaan diri dengan mengurangi maupun mengontrol kemarahan, penderitaan, stres, dan segala hal yang negatif (Jamal \& Thoif, 2009). Berdasarkan beberapa hasil penelitian serta pendapat yang disampaikan para ahli di atas, maka dapat terlihat jelas bahwa pemaafan merupakan salah satu hal yang dapat memberikan manfaat besar untuk membuat seseorang menjadi bahagia.

\section{DAFTAR PUSTAKA}

Anggoro, W. J \& Widhiarso, W. (2010). Konstruksi dan Identifikasi Properti Psikometris Instrumen Pengukuran Kebahagiaan Berbasis Pendekatan Indigenous Psychology: Studi Multitrait - Multimethod. Jurnal Psikologi, 37 (2), 176-188

Azis, R. (2011). Pengalaman Spiritual dan Kebahagiaan Pada Guru Agama Sekolah Dasar. Proyeksi, 6 (2), 1-11

Csikszentmihalyi, M., \& Hunter, J. Happiness in Everyday Life: The Uses of Experience Sampling. Journal of Happiness Studies, 4 (2), 185-199. 
Departemen Pendidikan dan Kebudayaan. (1990). Kamus besar bahasa Indonesia. Jakarta: Balai Pustaka.

Enright. (2001). Forgiveness is Choice Woshington DC. Amerika Psycological Association.

Fincham, F. D, Beach, S. R and Davila, J. (2004). Forgiveness and Conflict Resolution in Marriage. Journal of Family Psychology. 18, 72-81.

Franken, R.E. (2002). Human motivation (5th edition). Belmont: Wadsworth.

Ghani, A. H. (2011). Forgiveness therapy: Maafkanlah, niscaya dadamu lapang. Yogyakarta : Kanisius

Hadriami, E. (2008). Pemaafaan dalam Kaidah Kerukunan Hidup Orang Jawa. Psikodimensia, volume 7. Semarang: Fakultas Psikologi Universitas Katolik Soegijapranata.

Hall, J.H., Fincham, F.D., \& Beach, S.R.H. (2006). Forgiveness in marriage: Current Status and Future Directions. 55 (4), 415-427. http://greatergood.berkeley.edu/images/uploads/FinchamForgiveness in Marriage and_Future_Directions.pdf

Hurlock, E.B. (2000). Psikologi perkembangan rentang kehidupan. Jakarta: Erlangga.

Jamal, Z. T, dan Thoif (2009). Maafkanlah maka kamu akan sehat. Yogyakarta: Pintu Hati.

Jayanti.A.M. (2014). Ruqyah Syar'iyyah untuk Menurunkan Tingkat Stress Pada Lansia. Skripsi (Tidak Diterbitkan). Yogyakarta: Fakultas Psikologi dan Ilmu Sosial Budaya Universitas Islam Indonesia Yogyakarta. 1-2

Maltby, J., Giles, D. C., Barber, L., \& McCutcheon, L. E. (2005). Intense-personal celebrity worship and body image: Evidence of a link among female adolescents. British Journal of Health Psychology, 10, 17-32.

McCullough, M. E., Fincham, F. D., \& Tsang, J. (2003). Forgiveness, forbearance, and time: The temporal unfolding of transgression-related interpersonal motivations. Journal of Personality and Social Psychology. 84 (3), 540-557.

Mullet, E., Houdbine, A., Laumonier, S \& Girard, M. (1998). Forgivingness: Factor structure in a sample of young, middle-aged, and elderly adults. European Psychologist, 3 (4), 289-297

Nashori, F. (2011). Meningkatkan Kualitas Hidup dengan Pemaafan. Jurnal Unisia, 33, 75 . 
Paramitasari, R \& Alfian, I., N. (2012). Hubungan Antara Kematangan Emosi dengan Kecendrungan Memaafkan pada Remaja Akhir. Jurnal Psikologi Pendidikan dan Perkembangan, 1 (2), 1-7

Santoso, A., Lestari, N. (2008). Peran Serta Keluarga pada Lansia yang Mengalami Post Power Syndrome. Media Ners, 2 (1), 1-44.

Sastre, M., Vinsonneau, G., Neto, F., Girard, M., \& Mullet, E. (2003). Forgivingness and Satisfaction with Life. Journal of Happiness Studies, 4, 323-335.

Seligman, M.E.P. (2005). Authentic Happiness: Menciptakan kebahagiaan dengan Psikologi Positif. Bandung: Mizan.

Shihab, M.Q. (2002). Tafsir Al-Mishbah: Pesan, kesan, dan keserasian Al Qur'an Volume 2. Jakarta: Lentera Hati.

Shihab, M.Q. (2002). Tafsir Al-Mishbah: Pesan, kesan, dan keserasian Al Qur'an Volume 12. Jakarta: Lentera Hati.

Stanley M. \& Beare P. G. (2012). Buku Ajar Keperawatan Gerontik, Edisi 2. Jakarta: EGC

Toussaint, L. \& Friedman, P. (2009). Forgiveness, Gratitude, and Well-Being: The Mediating Role of Affect and Beliefs. Journal of happiness studies. 10, 6. 635 654.

Wardhati, L. T \& Faturochman. (2006). Psikologi Pemaafan. Buletin Psikologi. 14 (1). Yogyakarta: Fakultas Psikologi Universitas Gajah Mada.

Wismanto, A \& Tim psikologi kesehatan. (2011). Psikologi Kesehatan. Semarang: Penerbitan Universitas Katolik Soegijapranata.

Witvliet, C., Ludwig, TE., VanderLaan, KL. (2001). Granting Forgiveness or Harboring Grudges: Implications for Emotion, Physiology, and Health. Psychological Science, $12(2), 117-123$.

Wiyono, W \& Widodo, A. (2010). Hubungan Antara Tingkat Kecemasan Dengan Kecenderungan Insomnia Pada Lansia Di Panti Wredha Dharma Bhakti Surakarta. Jurnal ilmu Keperawatan, 2 , 2, 87-88.

Worthington, EL., Witvliet, CVO., Pietrini, P., Miller, AJ. (2007). Forgiveness, Health, and Well-being: A Review of Evidence for Emotional Versus Decisional Forgiveness, Dispositional Forgivingness, and Reduced Unforgiveness. Journal of Behavioral Medicine, 30, 291-302.

Zainuddin. K. (2011). Dendam dan Pemaafan dalam Konflik Antar Kelompok. Skripsi (Tidak Diterbitkan). Yogyakarta: Universitas Gadjah Mada. 